CZU: 37.013.31

https://doi.org/10.52507/2345-1106.2021-1.15

CALITATEA EDUCAȚIEI ȘI CERINȚELE ANGAJATORILOR LA INCEPUTUL SEC. XXI

MAHAJNA Alaa, doctorandă, ULIM,

Israel

GRIBINCEA Corina,

Doctor în economie, Universitatea de Studii Europene din Moldova 


\title{
REZUMAT
}

De mai multe secole, educația a rămas în mare parte intactă, fiind cel mai conservativ spațiu al eforturilor umane. Lucrurile evoluează și situaţia s-a schimbat dramatic odată cu intrarea umanității în era digitală. Competitivitatea absolvenților-specialiști, formată pe parcursul perioadei universitare, începe să se realizeze la antrenarea în câmpul muncii - în procesul de interacțiune cu angajatorii și se exprimă, primordial, în succesul activităţii resurselor umane după profilul specialității dobândite și cea suplimentară. Plonjarea în era tehnologiilor digitale în aproape toate domeniile vieții sociale şi economice permite economiștilor, politicienilor, sociologilor, oamenilor de știință să vorbească despre apariția celei de-a patra revoluții industriale. Scopul investigației constă în investigarea cerințelor angajatorilor față de absolvenți și specialiști pe piața muncii.

Cuvinte-cheie: absolvenți, specialiști, profesioniști de calitate înaltă, angajatori.

\section{QUALITY OF EDUCATION AND EMPLOYERS 'REQUIREMENTS AT THE BEGINNING OF THE 21ST CENTURY}

\author{
MAHAJNA Alaa, \\ PhD student, \\ Free International University of Moldova, \\ Israel \\ GRIBINCEA Corina, \\ $\mathrm{PhD}$ of Economics, \\ University of European Studies of Moldova
}

\begin{abstract}
SUMMARY
For centuries, education has remained largely intact being the most conservative space of human effort. Things are evolving and the situation has changed dramatically with the entry of humanity into the digital age. The competitiveness of graduates-specialists that are trained during the university period begins to be achieved during work process, in interaction with employers and is expressed in the success of the workforce according to the acquired and additional specialty. The plunge into the age of digital technologies in almost in all areas of social and economic life and allows economists, politicians, sociologists and scientists to talk about the emergence of the fourth industrial revolution. The purpose of the study is to investigate the requirements of employers towards graduates and specialists in the labor market.
\end{abstract}

Key words: graduates, specialists, highly skilled professionals, employers.

Introducere. Implementarea tehnologiilor digitale în aproape toate domeniile vieții sociale și economice permite economiștilor, politicienilor, sociologilor, oamenilor de știință să vorbească despre debutul celei dea patra revoluții industriale. Spre deosebire de a treia (electronică și tehnologii digitale, automatizare industrială, estompând liniile dintre sferele fizice, digitale și biologice), a patra revoluție industrială, care se sprijină pe tehnologii de rețea, a condus la o avalanșă radicală. Schimbările dinamice, pe scară largă și complexe în consecințele sale se schimbă nu numai în știință și economie, ci și în sfera socială, viața publică și privată, educația. În condițiile unui exces al ofertei pe piaţa muncii, este destul de anevoios pentru absolvenții universitari să reziste concurenței și să-și revendice locuri de muncă înalt plătite în comparație cu alte categorii de lucrători. În astfel de condiții, angajatorii sunt interesați să selecteze nu doar absolvenții cei mai performanți și talentați, ci și buni dintre cei mai buni, cu bune calităţi personale, profesionale, cu inteligență emoțională ridicată și cunoștințe de limbi străine.

Gradul de cercetare. Baza teoretică au constituit lucrările științifice ale lui I.L. Bachilo, I.Yu. Bogdanovskaya, A.B. Vengerov, D.A. Kerimov, G.V. Maltsev, B.C. Nersesyants, Yu.A. Nisnevici, A.S.
Pigolkin, S. Polenin, V.M. Syrykh, L.K. Tereshchenko, A.A. Fatyanov, L.V. Filatov, P.O. Khalfin și alți savanți. Alte lucrări au fost consacrate teoriei informației, globalizării (K. Shannon, E. Toffler, P.Drucker, M.Castells, D.Sichel, T.Forester) fiind importante pentru dezvoltarea conceptului societății informaționale, determinând gradul de influență al globalizării asupra dezvoltării sale. $\mathrm{Cu}$ toate acestea, problemele strategiei și direcțiilor de dezvoltare al vectorului Revoluției 4.0 în domeniul educației nu sunt clare, deoarece angajatorii nu pot formula clar cerințele.

Scopul studiului constă în studiul pieței muncii și determina impactul globalizării, digitalizării, Revoluției 4.0, economiei mondiale asupra dezvoltării țărilor și rolul statului în asigurarea personalului calificat întru stabilizarea economică și cerințele pieței muncii.

Baza metodologică a cercetării constă în elaborarea teoretică a problemei societății postindustriale, prezentată în lucrările autorilor autohtoni și străini, caracteristicile conținutului structurii sistemele educaționale în perioada de formare și dezvoltare a acesteia. Aplicarea teoriei societății postindustriale ca bază a studiului problemelor de structură a pieței muncii. Autorii în timpul investigației au utilizat sistemul și metodele structural-sistemice, metoda comparativă, 
metoda de analiză și sinteză, inducție și deducție, istorică, statistică, de previziune etc.

Rezultate și analiză. Realizarea aspiraţiilor spre o viaţă mai decentă, corectă își găsește confirmarea directă în practică, dovada fiind rezultatele numeroaselor studii. Majoritatea angajatorilor sunt obligați să refuze angajarea absolvenților universitari, argumentând acest lucru, primordial, prin izolarea cunoștințelor și abilităților dobândite de condițiile de producție reală, precum și prin lipsa practicii de muncă după specialitate. În acest sens, problema selectării, pregătirii universitare a specialiștilor la nevoile pieței muncii devine stringentă.

Astfel, pentru a pregăti specialiști competitivi care ar fi capabili să găsească cu succes un post în profilul specialității lor, universitățile trebuie să ia în calcul cerințele angajatorilor. Pentru a îndeplini această sarcină, trebuie mai întâi să se studieze cerințele relevante. În acest sens, scopul studiului nostru este de a concretiza abilitățile, caracteristicile, calitățile, cunoștințele, aptitudinile, abilităţile, metodele de comunicare care asigură competitivitatea absolvenților universitari pe piața muncii. Obiectul studiului a fost alcătuit din angajatori care angajează absolvenți universitari în conformitate cu profilul specialităţii dobândite (,Managementul personalului”) [4]. Subiectul cercetării este competența unui absolvent universitar competitiv, cu o diplomă în managementul resurselor umane. Baza eșantionului pentru determinarea setului de competențe ale unui absolvent universitar competitiv în specialitatea „Management personal” a fost bazat pe disponibilitatea angajatorului de a angaja un absolvent în conformitate $\mathrm{cu}$ calificarea unui manager al specialității management personal. Conform acestui criteriu, 300 de angajatori au fost incluşi în eșantion.

Tabelul 1. Repartizarea priorităților profesionale la angajatori și tineri specialiști [4]

\begin{tabular}{|l|l|l|l|l|l|}
\hline Nr. & Aprecierea angajatorilor & $\begin{array}{l}\% \text { din } \\
\text { total }\end{array}$ & Aprecierea absolventului & $\begin{array}{l}\% \text { din } \\
\text { total }\end{array}$ \\
\hline 1 & $\begin{array}{l}\text { Concentrarea pe autorealizare } \\
\text { profesională }\end{array}$ & 55 & $\begin{array}{l}\text { Concentrarea pe promovarea } \\
\text { profesională }\end{array}$ & 55 \\
\hline 2 & $\begin{array}{l}\text { Orientarea către o evaluare adecvată a } \\
\text { potențialului profesional personal }\end{array}$ & 52 & Miza pe salariu ridicat & 54 \\
\hline 3 & $\begin{array}{l}\text { Orientarea la corelarea obiectivelor } \\
\text { personale și corporative }\end{array}$ & 48 & $\begin{array}{l}\text { Orientarea spre autorealizarea } \\
\text { profesională }\end{array}$ & 44 \\
\hline 4 & Orientarea spre promovarea profesională & 41 & Orientarea spre studii suplimentare & 34 \\
\hline 5 & $\begin{array}{l}\text { Orientarea spre studii suplimentare } \\
\text { personale și corporative }\end{array}$ & 37 & $\begin{array}{l}\text { Orientarea la corelarea obiectivelor } \\
\text { per }\end{array}$ & 32 \\
\hline
\end{tabular}

Comparând orientările motivaționale ale activităţii profesionale în evaluările angajatorilor şi ale absolvenților înșiși, se poate dezvălui o anumită discrepanță, care este o consecință a nepotrivirii nevoilor lor. Deci, în evaluările absolvenților, domină orientările motivaționale, asociate cu satisfacerea a două grupuri de nevoi inerente acestei grupe de vârstă a lucrătorilor statutul (orientarea spre servicii și avansarea profesională $55,5 \%$ ) și mijloacele de subzistență (orientarea către nivelul salariilor 53,7\%). Satisfacția acestor grupuri de nevoi le va permite absolvenților școlari / universitari să ocupe un loc demn în structura ierarhic organizată a societății, să dobândească un anumit grad de independență în plan profesional și economic.

Potrivit estimărilor angajatorului, printre liniile motivaționale ale absolvenților, prioritatea este orientarea către autorealizarea profesională $(54,0 \%)$ și orientarea către o evaluare adecvată a potențialului profesional personal $(51,4 \%)$, care se sprijină pe nevoia pentru o muncă semnificativă. Astfel, angajatorul este interesat de un absolvent care este gata să înceapă să-și realizeze potențialul dintr-o poziție de bază pentru o remunerație materială modestă, iar absolventul însuşi, adesea absolut fără experiență profesională, este interesat de o creștere a carierei garantată, în principal într-o companie, cu un nivel iniţial ridicat al salariilor.

La Târgului locurilor de muncă din Chișinău și Târgului on-line, care se desfãșoară de câțiva ani, sunt prezenți de obicei 40-50 agenți economici, prestând peste 6500 locuri vacante. Căutarea locurilor de muncă vacante poate fi realizată online pe $w w w$. e-angajare. $m d$. Deși la Târg au participat peste 2000 de vizitatori (2017-2018), doar 600 au găsit oferte interesante, iar contracte au încheiat doar unități. Deși remunerarea pentru un bucătar începător constituie peste $10.500 \mathrm{MDL}$, frecvent ofertele rămân vacante. In majoritatea cazurilor solicitanții de locuri vacante compară ofertele salariale cu cele de peste hotare, unde pot emigra lejer [8; 9].

Vis-à-vis de viața socială, dezvoltarea tehnologiilor digitale, umanitatea a intrat într-o nouă perioadă a dezvoltării sale civilizaționale - este o societate în rețea care formează o nouă cultură în rețea, conștientizată, acoperind sferele spiritualității, interacțiunii sociale, tehnologiei. Societatea în rețea este caracterizată de noi relații între oameni, maşini și natură (IoT, neuronet), disponibilitatea universală a cunoașterii, predominanța valorii interacțiunii asupra primatului instituțiilor, personalizarea mai degrabă decât caracterul de masă. Pe baza analizei datelor mari, se dezvoltă o nouă metodologie de știință, educație, medicină etc. Absolvenții deja trebuie sa fie pregătiți pentru cerințele pieței muncii [1]. Internetul global, dezvoltarea rețelelor sociale au dus la o nouă identitate umană „online”. Cea mai importantă sarcină este dezvoltarea proceselor de gestionare a propriei identități, inclusiv în rețelele sociale. Noile metode progresiste și mecanisme pentru formarea spiritualităţii, eticii, moralităţii într-o societate în rețea, al cărei centru este o persoană care poate extinde infinit cunoştințele, un set de conexiuni, direcții și modalități de interacțiune, capătă o importanță 
fundamentală.

Unicitatea Revoluției 4.0 constă în armonizarea și integrarea crescândă a unui evantai numeros de multiple discipline știinţifice, ceea ce impune cereri diferite sistemului de învățământ. Aceasta este, formarea abilităţilor cognitive şi sistemice, abilităţi pentru rezolvarea problemelor complexe, crearea de noi cunoştinţe și prelucrarea datelor, comunicarea, gestionarea resurselor şi propriul comportament, modelarea calităților personale ale elevilor/studenților etc.

Dezvoltarea tehnologiilor digitale și a rețelelor sociale a condus la renovarea bazei valorice-semantice a societății și a educației. Apare un nou tip de elevi/studenți care își formează în mod independent traiectoria educațională, care vizează autoeducarea, autoactualizarea și auto-dezvoltarea, combinând studiul, munca și dezvoltarea personală [3]. Viitorul (și prezentul) rezidă în tehnologiile educaționale în rețea care vor oferi personalizarea procesului educațional (inclusiv învăţarea la cerere) şi libertatea academică a elevilor/studenților în alegerea conținutului, formelor, metodelor, locului și timpului de învățare[6].

Astfel, în sfera socio-culturală dintr-o societate în rețea, au loc chiar mai multe transformări globale și la scară largă, schimbând radical (sau testând critic) felul în care trăim, învățăm, lucrăm și ne raportăm la noi înșine și unul la celălalt.

Israelul este astăzi una dintre țările de frunte în ceea ce privește știința și educația[2]. Sistemul său universitar a fost modelat după modelul american și este unul dintre cele mai tinere din lume, dar în același timp unul dintre cele mai puternice.

Tabelul 2.Cele mai prestigioase universități din Israel, 2021 [10]

\begin{tabular}{|l|l|l|l|}
\hline Clasamentul & Rangul mondial & Universitatea & Gradul de impact \\
\hline 3 & 73 & Tel Aviv University & 165 \\
\hline 6 & 165 & Hebrew University of Jerusalem & 225 \\
\hline 12 & 226 & Technion Israel Institute of Technology & 421 \\
\hline 15 & 244 & Weizmann Institute of Science & 401 \\
\hline
\end{tabular}

Tabelul 3.Cele mai prestigioase universități din Moldova, 2021 [11]

\begin{tabular}{|l|l|l|l|}
\hline Clasamentul & $\begin{array}{l}\text { Rangul } \\
\text { mondial }\end{array}$ & Universitatea & $\begin{array}{c}\text { Gradul } \\
\text { impact }\end{array}$ \\
\hline 1 & 3392 & Universitatea tehnică din Moldova & 7179 \\
\hline 2 & 3825 & Universitatea de Stat din Moldova & 5839 \\
\hline 3 & 7052 & Universitatea de stat de Medicină și Farmacie & 9896 \\
\hline 4 & 7624 & Universitatea de Stat Alecu Russo din Bălți & 9954 \\
\hline 5 & 8792 & Universitatea Cooperatist-Comercială din Moldova & 6054 \\
\hline 6 & 40609 & Academia de Studii Economice din Moldova & 8415 \\
\hline 7 & 12112 & Universitatea Liberă Internațională din Moldova & 10312 \\
\hline 8 & 12180 & Universitatea Pedagogică de Stat Ion Creangă & 10392 \\
\hline 9 & 13215 & Universitatea de Stat Transnistreană Taras Șevcenko & 11667 \\
\hline 10 & 13885 & Universitatea de Stat din Tiraspol & 16369 \\
\hline 11 & 13911 & Universitatea Agrară de Stat & 12519 \\
\hline 12 & 15627 & Universitatea de Stat din Comrat & 14624 \\
\hline 13 & 16034 & Academia de Muzică, Teatru și Arte Plastice & 15095 \\
\hline 14 & 16982 & Universitatea de Stat din Cahul B. P. Hașdeu & 16223 \\
\hline 15 & 17692 & Academia de Administrație Publică & 17020 \\
\hline 16 & 18802 & Universitatea de Studii Europene din Moldova & 18279 \\
\hline
\end{tabular}

Webometrics formând ratingul universităților a luat în considerație:

$50 \%$ - vizibilitatea - numărul total de linkuri externe

10 \% - transparența - numărul total de citări

$40 \%$ - excelența - calitatea articolelor științifice publicate

Principala sursă de schimbare nu este educația în sine, ci un set de provocări cu care se confruntă, inclusiv noi contexte tehnologice, politice, sociale, culturale şi economice, factori de complexitate și incertitudine. Digitalizarea sistemului mondial educațional a ușurat accesul la educația de elită pentru masele largi [4]. Actualmente are loc tranziția la educație bazată pe Big Data, când sistemul analizează o cantitate mare de date despre activitățile educaționale ale elevilor/studenților și sugerează calea educațională optimă. Clasamentul țărilor mondiale după nivelul activităţii de R\&D este o analiză comparativă a informației statistice vizând numărul de articole de cercetare publicate de reprezentanții comunităților științifice naționale în reviste științifice evaluate de colegi. Volumul publicațiilor de R\&D evaluate de colegi oferă o imagine de ansamblu asupra activităţii de cercetare și tehnologie din întreaga lume, precum și pentru țări individuale. Indicatorul nivelului activităţii de cercetare este considerat unul dintre indicatorii cheie ai dezvoltării științifice și tehnologice a țării și este calculat ca numărul total de articole publicate ca rezultat al cercetărilor în reviste științifice și publicații revizuite de colegi, inclus în Science Citation Index (SCI) și Social Sciences Citation Index (SSCI). 
Tabelul 4.Evaluarea țărilor din lume pe nivelul de activitate științifică [7]

\begin{tabular}{|l|l|l|l|l|l|}
\hline clasare & Tara & Nr. art. & clasare & Țara & Nr. art. \\
\hline 1 & China & 528263 & 6 & Marea Britanie & 97681 \\
\hline 2 & SUA & 422808 & 7 & Rusia & 81579 \\
\hline 3 & India & 135788 & 33 & Israel & 12235 \\
\hline 4 & Germania & 104396 & 40 & România & 10345 \\
\hline 5 & Japonia & 98793 & 113 & Moldova & $\mathbf{2 1 0}$ \\
\hline
\end{tabular}

Informația prezentată denotă că cercetarea științifică ocupă un loc major în dezvoltarea științei, materialelor noi şi tehnologiilor de vârf, sporind exportul şi competitivitatea produselor și țării. În prezent, este deosebit de important să se definească în mod clar ceea ce include conceptul de „educaţie generală fundamentală" - atât din punct de vedere al conținutului său, cât și ținând cont de vârsta elevului/studentului. Formarea unei societăți de rețea este personificată, variată, devenind un tip de ,matrice de posibilităţi” a unei persoane de-a lungul vieții sale [5]. Nu ar trebui doar să formeze imaginea știinţifică a lumii a unei persoane, ci, în același timp, să creeze condiții pentru dezvoltarea sa personală, formarea competențelor pentru o viaţă de succes, eficientă și sigură și să satisfacă orice nevoi educaţionale care se schimbă rapid.

Concluzii. Actualmente, liderii educaţionali insistă că instruirea ar trebui să devină preocuparea angajatorilor. Această afirmație contrazice practicii, deoarece angajatorul este contribuabil și plătește impozite către stat, care ar trebuie să asigure funcționarea bună a universităților, menite să adapteze studenții la condițiile specifice ale anumitor întreprinderi. Principala preocupare a businessului nu este formarea personalului, ci adaptarea lui la condițile pieței muncii. Acest lucru este confirmat și de materialele sondajelor efectuate în rândul angajatorilor. În ciuda imperfecțiunii standardelor educaţionale existente, universităţile, pentru a fi solicitate, trebuie să formeze specialiști care să îndeplinească pe deplin cerințele angajatorilor. Din aceste motive instituțiile de învățământ sunt în contact continuu cu angajatorii pentru a determina de care specialiști și care abilităţi și deprinderi trebuie să posede. Universitățile împreună cu angajatorii ajustează procesul educaţional prin introducerea de noi cursuri de formare (modificând gama sortimentală a ofertei), astfel încât să îndeplinească cerințele pieței muncii. Cea mai preferabilă opţiune pentru îndeplinirea cerinţelor angajatorului este plasarea disciplinelor în blocul opțional (fără a încălca cerinţele Standardului educaţional de stat). Toate doleanțele angajatorilor pot fi grupate în două grupuri cerințe profesionale și cerințe personale. Pe lângă abilităţile de utilizare a materialelor noi și tehnologiilor de vârf, digitalizării, IoT eficient, tânărul specialist trebuie să posede calităţi personale ca: lipsa supraestimării; stabilitate psihologică; adaptarea lucrului în echipă; activitatea eficientă pentru rezultat final; proiectarea unui lanț logic al activității până la final; gândire inovatoare - perceperea informațiilor noi; rezistență la stres; încredere în sine; capacitatea de a formula şi a transmite în mod clar ideea către interlocutor; abilități de comunicare etc.

\section{Referinte bibliografice:}

1. Abu Madean Saad, Elkrinawi Khalid, Kouzly Rabah. Metodologia managementului educational. Conferinţa ştiinţifico-practică internaţională "Ştiinţă, educaţie, cultură", 11 februarie 2021, Comrat: USC, 2021, p. 421- 425.

2. Amar Ravit, Gribincea A. Creativity as a factor of innovative sustainable economic development. Conferința "World economy and international economic relations", vol. 3, Chișinău, Moldova, 1 ianuarie 2020, p. 67-71.

3. Awawdi Badera, Fayed Khatib Nasreen, Haj Remah. Managementul calității educaționale. Conferința ştiinţificopractică internațională "Știință, educație, cultură", 11 februarie 2021, Comrat: USC, 2021, p.25- 428.

4. Cerintele angajatorilor. https ://studref. com/ trebovaniya_rabotodateley. (Vizitat 12.02.2021)

5. Gribincea A. Content of intellectual property rights. În: revista EcoSoEn, nr. 3-4, 2020, p.72-78.

6. Gribincea C., Gribincea A. Direcțiile care vor determina viitorul apropiat. Conferinţa internaţională "Ştiinţă, educaţie, cultură", 11 februarie 2021, Comrat: USC, 2021, p.28-32.

7. National Science Foundation: Science and Engineering Indicators 2019. https ://gtmarket. ru/ ratings/ scientific and -technical-activity. (Vizitat 21.01.2021)

8. Noutăți și evenimente. https ://motivație. $\mathrm{md} /$ index. php? pag= news\& id $=1060$ \&rid $=783$ \&l =ro. (Vizitat 18.02.2021)

9. Rezultatele târgului locurilor de muncă din Chișinău. https ://www. anofm .md/ en/ node/1755. (Vizitat 11.01.2021)

10. Topul celor mai bune universități din lume din 2021. https ://diez. md/2021/01/31 /topul- celor-mai-buneuniversitati-din-lume-din-2021-editia-lunii -ianuarie -iată -instituțiile-care -dețin -întâietatea/.(Vizitat 24.01.2021)

11. Topul celor mai bune universități din Moldova în anul 2021. https ://diez. md/ 2021/ 01/27 /topul- celor- maibune- universități- din-moldova-in-anul-2021-potrivit-raportului-webometrics - ediția -iarna/(Vizitat 18.02.2021). 